Reprod. Nutr. Dévelop., 1988, 28 (2 A), 211-228.

\title{
Structure and structure-function relationships in gonadotropins
}

\author{
Y. COMBARNOUS
}

Station de Physiologie de la Reproduction, I.N.R.A. Nouzilly, 37380 Monnaie, France.

Pituitary gonadotropins ( $\mathrm{LH}\left({ }^{1}\right)$ and FSH) as well as chorionic gonadotropins (CG) are glycoprotein hormones and, as such, are the most complex molecules with hormonal activity known so far. Because of their structural complexity and their primordial role in gonadal functions, the structure-function relationships of gonadotropins are of utmost interest for both the protein chemist and the reproductive endocrinologist.

\section{Structure of gonadotropins}

All gonadotropins consist of two different non-covalently bound subunits called $\alpha$ and $\beta$, each bearing one or several carbohydrate moieties. The polypeptide chain sequence of the $\alpha$-subunit is common to all glycoprotein hormones (including TSH) in one given species, while the $\beta$-subunits exhibit hormone-specific amino-acid sequences (fig. 1). Reported molecular weights for gonadotropins are approximately 28000 for LH, 34000 for FSH (Liu and Ward, 1975), 37000 for human CG (Birken and Canfield, 1978) and 45000 for equine CG (Combarnous et al., 1981). The molecular weights of the polypeptide portions of $\mathrm{LH}$ and FSH on one hand and of hCG and $\mathrm{eCG}$ on the other hand are similar. Their carbohydrate contents $(18-45 \%)$ differ somewhat and seem to be responsible for the differences in molecular weight (Combarnous et al., 1984a, b). The structures of the protein and carbohydrate moities will be considered first before we study their involvement in the biological properties of gonadotropins.

(1) Abbreviations :

Hormones: LH : Luteinizing Hormone ; FSH : Follicle-Stimulating Hormone ; TSH : ThyroidStimulating Hormone; CG : Choriogonadotropin; PMSG : Pregnant Mare Serum Gonadotropin (= equine CG). DG-hCG : deglycosylated hCG.

Species : h : human ; b : bovine ; cam : camel ; e : equine ; 0 : ovine ; $p$ : porcine ; $r$ : rat.

Others : NANA : N-acetyl neuraminic acid (sialic acid); Gal : galactose ; GlcNAc : N-acetyl glucosamine; GalNAc : N-acetyl galactosamine; Man: mannose ; Fuc : fucose; Asn : Asparagine ; Ser : Serine; Thr : Threonine. 


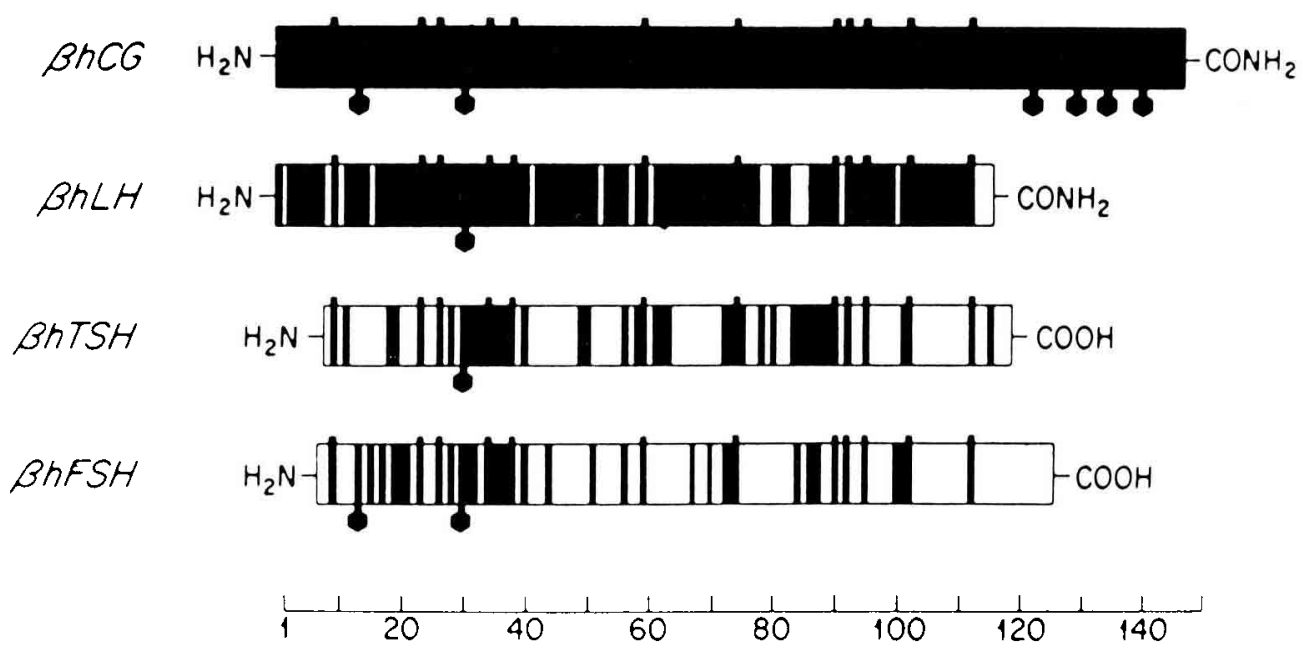

FIG. 1. - Comparison of primary structures of human glycoprotein hormone $\beta$-subunits. The abcissa indicates amino-acid residue positions. The regions in black are those occupied by identical residues in the different molecules, taking $\mathrm{hCG} \beta$ as the reference. The small dots on top of each scheme indicate the positions of half-cystine residues which are all conserved in the different molecules. The hexagones below each scheme show the positions of polysaccharide moieties. The common regions in the different $\beta$-subunits are believed to be mainly involved in binding with the common $\alpha$-subunit (taken from Bidard et al.).

A. Polypeptide structure of gonadotropins.

1. Primary structure. - The common $\alpha$-subunit polypeptide chain of glycoprotein hormones is the product of one single gene (Boothby et al., 1981). It contains 90-96 amino-acid residues, depending on the species (Pierce, 1976 ; Strickland et al., 1985) and, in a given species, it exhibits some heterogeneity of length at the $\mathrm{N}$-terminus. The $\beta$-subunit is constituted of $118-121$ residues in most pituitary hormones (Pierce, 1976), but chorionic gonadotropins (Birken and Canfield, 1978 ; Moore et al., 1980) and also equine LH $\beta$-subunits (Bousfield et al., 1985) exhibit an additional C-terminal polypeptide portion (CTP) and are 145residues long. The $\alpha$ - and $\beta$-subunits contain 5 and 6 disulfide bridges, respectively, and their positions are identical in all hormones. Since hybrid molecules can be made up with subunits from different hormones, it is obvious that polypeptide portions involved in the association of the subunits are very similar or identical in the different hormones. Accordingly, amino-acid residues from unvariable polypeptide portions in the different $\beta$-subunits have been found to be accessible to solvent medium in the free subunits and buried in the native hormones (Yang and Ward, 1972 ; Combarnous and Maghuin-Rogister, 1974b ; Combarnous and Hennen, 1976 ; Liu and Ward, 1976). 
2. Secondary structure. - Circular dichroism studies indicate that gonadotropins have an extremely low $\alpha$-helical content but exhibit rather large portions of $\beta$-structure (Garnier et al., 1975 ; Giudice and Pierce, 1978). However, the largest portions of the polypeptide chains are present as aperiodic structures. Prediction analyses based on their amino-acid sequences also indicate a significant level of $\beta$-structrure and dominant aperiodic structures. This does not mean that gonadotropins have no precisely determined secondary structure as in urea-denatured polypeptides (random coil). In contrast, the aperiodic regions of gonadotropins are very well defined structures since many residues are unavailable to chemical or enzymatic modification in the native hormones as well as in their free subunits.

Circular dichroism analyses of native gonadotropins and their free subunits show that, upon recombination, there is an increase in the contribution of $\beta$ structures at the expense of aperiodic structures (Garnier et al., 1975 ; Giudice and Pierce, 1978 ; Combarnous and Maghuin-Rogister, 1974a). This might be due to changes in the conformation of one or both subunits, but we also propose the hypothesis that when $\beta$-sheet regions from the two subunits come into contact, they form a single larger $\beta$-sheet which contributes more to far UV circular dichroism than the two parent structures. Such a structure would certainly have a strong, favorable effect on the association stability of the subunits.

3. Tertiary structure. - The first information on the tertiary structure of proteins is given by the position of their disulfide bridges. Since the half-cystine residues of all glycoprotein hormones occupy identical positions in their sequences, it is generally accepted that their disulfide bridges are identical. In the $\alpha$-subunit, half-cystine residues are very close to each other in primary structure (four groups of two or three residues). Proteolysis of the subunit by different enzymes such as trypsin, chymotrypsin, thermolysin or pepsin leads to the obtention of a polypeptide containing all five disulfide bridges. Outside this core, the polypeptide portions without half-cystines form three buckles, easily digested by proteolytic enzymes. Because of the close vicinity of disulfide bridges in the $\alpha$ subunit of glycoprotein hormones, it was difficult to assign their pairing, and the proposals of different laboratories disagreed (Chung et al., 1973 ; Cornell and Pierce 1974 ; Combarnous and Hennen, 1974a, b ; Mise and Bahl, 1980 ; Fujiki et al., 1980). The half-cystine residues in the $\beta$-subunit are more evenly distributed along the amino-acid sequence and consequently their pairing is less controversial (Chung et al., 1975 ; Reeve et al., 1975 ; Tsunasawa et al., 1977 ; Mise and Bahl, 1980). After complete reduction and reoxidation, the disulfide bridges of the $\mathrm{hCG} \alpha$ subunit can be reconstituted correctly in vitro. In the same conditions, the amount of correctly folded $\mathrm{hCG} \beta$-subunit obtained in vitro is significantly increased by removal of the carbohydrates (Goverman et al., 1982). The situation may be different in vivo as an oligosaccharide moiety must be attached to allow correct folding of the $\beta$-subunit of bLH, translated in a system derived from Krebs ascites tumor cells (Strickland and Pierce, 1985).

For the time being, the crystallization of glycoprotein hormones has never succeeded, preventing $X$-ray crystallographic analysis of their three-dimensional 
structure. Nevertheless, indirect approaches such as chemical and enzymatic modifications of amino acid side-chains, have given many clues to the conformation of gonadotropins. An excellent review on this matter, concerning LH and CG, has recently been published (Gordon and Ward, 1985).

4. Quaternary structure. - This structural order corresponds to the noncovalent binding of subunits. Free subunits are totally devoid of gonadotropic activity and their association is mandatory for the expression of the activity specified by the $\beta$-subunit. Upon binding, conformational changes can be evidenced by different physico-chemical and immunological techniques, confirming that the functional binding site is not present in either subunit. Three hypotheses can be proposed concerning the contribution of the two subunits to hormonal activities : a) the specific binding sites are present on the different $\beta$ subunits but achieve their appropriate conformation only after binding with the $\alpha$ subunit which serves as a template $; b$ ) the potential binding site is borne by the $\alpha$-subunit and the specific conformations are induced by the different $\beta$-subunits ; c) the construction of the binding site requires the correct alignment of the residues contributed by both subunits (with the possible mutual conformational influence of the two subunits).

The data on the recombination kinetics of hCG subunits indicate that they form an intermediate complex which then undergoes a conformational rearrangement to form the native structure $\alpha+\beta \leftrightarrow \alpha \beta \leftrightarrow \mathrm{H}$ (Ingham et al., 1976). The kinetic and equilibrium parameters of association and dissociation of the subunits of $\mathrm{pLH}, \mathrm{oLH}$ and $\mathrm{hCG}$ at neutral $\mathrm{pH}$ and $37^{\circ} \mathrm{C}$, give $\mathrm{Kd}$ values of $7.10^{-8} \mathrm{M}, 4 \cdot 10^{-7} \mathrm{M}$ and $6 \cdot 10^{-7} \mathrm{M}$ respectively (Strickland and Puett, 1982 ; Forastieri and Ingham, 1982). These values are considerably higher than physiological concentrations $\left(10^{-11}\right.$ to $\left.10^{-9} \mathrm{M}\right)$ and therefore, at equilibrium, the gonadotropins should be completely dissociated at physiological concentrations. This is of course not the case because dissociation is a very slow process $\left(t_{1 / 2}\right.$ 11-46 days) compared to clearance from the circulation $\left(t_{1 / 2} 5 \mathrm{~min}-5 \mathrm{~h}\right)$.

Using a water-soluble carbodiimide, we were the first to establish a covalent bond between the subunits of a glycoprotein hormone with retention of biological activity (Combarnous and Hennen, 1974b). Since then, this technique has been used by several laboratories to cross-link the subunits of other glycoprotein hormones (Parsons and Pierce, 1979; Weare and Reichert, 1979a). It has been shown that the bridge between the subunits of bLH is established by covalent coupling of the side-chains of Lys $\alpha-49$ and Asp $\beta-111$ (Weare and Reichert, 1979b).

The carbohydrate moieties have been shown to have a negative effect on the stability of the quaternary structure of hCG (Manjunath and Sairam, 1983), oLH (Sairam and Manjunath, 1982a ; Bewley and Sairam, 1985) and oFSH (Sairam and Manjunath, 1982b). Indeed, after heating at $100{ }^{\circ} \mathrm{C}$ for $10 \mathrm{~min}$, DG-hCG subunits reassociate in less than $4 \mathrm{~h}$ at $37^{\circ} \mathrm{C}$, while more than $72 \mathrm{~h}$ are needed for the complete recovery of receptor-binding activity in native hCG (Manjunath and Sairam, 1983). 


\section{B. Carbohydrate structure of gonadotropins.}

1. Position of carbohydrate chains. - All glycoprotein hormones contain several Asn-linked oligosaccharides. Two oligosaccharide chains are present on $\alpha$ subunits on Asn residues in positions 56 and 82. Two chains are found on Asn residues in positions 13 and 30 of $\mathrm{FSH} \beta$, one chain on Asn 13 of $\mathrm{LH} \beta$ and one chain on Asn 30 of $\mathrm{TSH} \beta$. In contrast to other species, the $\beta$-subunit of human LH has been found to bear carbohydrate chains on the two Asn residues in positions 13 and 30. Asparagine residues bearing carbohydrate chains are invariably followed by a hydroxyamino acid (Ser, Thr) in the second position on the Cterminal side (Asn-Xxx-Ser/Thr). This triplet is thus a necessary (but not a sufficient) prerequisite for the occurrence of $\mathrm{N}$-glycosylation.

Some O-linked oligosaccharides are also found in gonadotropin subunits. First, hCG and eCG $\beta$-subunits bear short oligosaccharide chains on serine residues located on their additional CTP. Second, bovine pituitary has been shown to secrete an $\alpha$-like glycoprotein with the same amino acid sequence as the $\alpha$ subunit of gonadotropins, but bearing an O-glycosidic unit on Thr 43 in addition to the two usual $\mathrm{N}$-glycosidic chains (Parsons et al., 1983). The presence of this additional carbohydrate chain impedes the binding of this molecule to any $\beta$-subunit because of steric hindrance (Parsons and Pierce, 1984). This indicates that the polypeptide region containing Thr $\alpha-43$ is located at the surface of the free $\alpha$-subunit and is either directly involved in the interaction with the $\beta$-subunit or very close to the binding area. The human placenta has also been shown to be the source of an overgly cosylated $\alpha$-subunit unable to bind to the $\beta$-subunit (Nishimura et al., 1983). It has not been demonstrated yet, however, that this subunit is similar to that found in bovine pituitary.

2. Structure of carbohydrate chains. - Polysaccharidic chains of glycoprotein hormones are of the "complex" type as opposed to the "mannose-rich" type. Table I shows the structures of the inner core and different peripheral branches $(\mathrm{PB})$ of the oligosaccharide chains of gonadotropins.

TABLE 1

Structures of N-linked oligosaccharides in gonadotropins.

\begin{tabular}{|c|c|c|}
\hline & Peripheral branches (PB) & Inner core \\
\hline $\begin{array}{l}\text { 1) } \\
\text { 2) } \\
\text { 3) } \\
\text { 4) } \\
\text { 5) } \\
\text { 6) }\end{array}$ & $\begin{array}{r}\text { Gal-GlcNAc-Man- } \\
\text { NANA-Gal-GlcNAc-Man- } \\
\text { GalNAc-GIcNAc-Man- } \\
\mathrm{SO}_{4} \text {-GalNAc-GlcNAc-Man- } \\
\text { Man-Man- } \\
\text { Man }>\text { Man- } \\
\text { Man }\end{array}$ & $\begin{aligned} \mathrm{PB}>-\mathrm{Man}-\mathrm{GicNAC}-\mathrm{Gl} N \mathrm{IAc}-\mathrm{ASN} \\
\pm \mathrm{Fuc}\end{aligned}$ \\
\hline
\end{tabular}

NANA : N-acetyl neuraminic acid (sialic acid) ; Gal : galactose ; GlcNAc : N-acetyl glucosamine ; GalNAc : N-acetyl galactosamine ; Man : mannose ; Fuc : fucose. 
Identical or different $\mathrm{PB}$ can be present in the same chain. Bovine $\mathrm{LH}$ bears only neutral (PB1, PB3, PB5, PB6) and sulfated (PB4) olisaccarides, hFSH contains exclusively neutral and sialylated (PB2) structures, and most others contain all three types of oligosaccharides. For example, hLH, hTSH and oFSH contain dibranched complex oligosaccharides which bear PB3 or PB4 on one branch and PB1 or PB2 on the other (Green et al., 1986). A comparison of the carbohydrate structure of the $\alpha$-subunits of all human glycoprotein hormones indicates that they differ considerably although their polypeptide sequences are identical (Nilsson et al., 1986). This is particularly interesting in the case of hLH and hFSH $\alpha$ subunits which are believed to be synthesized by the same cells. It has been suggested that the divergencies in glycosylation of $\alpha$-subunits could arise because of different conformational features caused by a combination with the respective nonidentical $\beta$-subunits.

The structure of O-glycosidic units on the CTP of chorionic gonadotropins is much simpler than $\mathrm{N}$-glycosidic chains (Kessler et al., 1979) :

\section{NANA-Gal-GalNAc-SER NANA}

The structure of the O-glycosidic chain of the $\alpha$-like molecules found in the bovine pituitary is not yet fully determined but it has been shown to contain NANA and no SO4- NAcGal, in contrast to the two $\mathrm{N}$-linked oligosaccharidic chains of bLH $\alpha$.

3. Polymorphism. - The pleomorphism of glycoprotein hormones has long been recognized with respect to molecular charge (Jutisz and Squire, 1958; Courte et al., 1971). As the number and properties of isohormones vary, depending on the physiological status of the animal, it is of particular interest to determine their structural origin. Charge polymorphism has been demonstrated for almost all glycoprotein hormones studied so far, as well as for their $\alpha$ - and $\beta$ subunits. Therefore, the theoretical number of hormone isoforms is the product of the number of $\alpha$ forms and the number of $\beta$ forms. One exception seems to be camel LH for which only one form was detected by chromatofocusing (Anouassi et al., 1987).

A comparison of isoforms of hCG showed a close relationship between their pls and sialic acid contents (Nwokoro et al., 1981). The involvement of sialic acid content in polymorphism has been demonstrated for eLH (Matteri and Papkoff, 1987), rLH (Hattori et al., 1985), hFSH (Wide, 1982) and rat FSH (Blum et al., $1985)$ by the fact that removal of sialic acid residues alters polymorphism significantly. However, polymorphism is not completely abolished by this treatment. Moreover, the content in sialic acid of the numerous isoforms of human LH does not vary to any great extent (Stockell Hartree et al., 1985). Therefore, even when present, sialic acid residues are not the only factor responsible for heterogeneity in gonadotropins. It can be postulated that the degree of sulfation in hormones known to contain no sialic acid, but sulfated $\mathrm{N}$ acetyl galactosamine, is chiefly responsible for the observed polymorphism. 
Although it is established that much of the pleomorphic nature of glycoprotein hormones is due to their carbohydrate moiety, it must also be kept in mind that heterogeneity at the $\mathrm{N}$-terminus of $\alpha$-subunits is observed in many species and that the structure of some $\alpha$ and $\beta$-subunit molecules has nicked polypeptide bonds (Courte and Willemot, 1972 ; Ward et al., 1986).

\section{Structure-function relationships of gonadotropins}

The overall in vivo activity of gonadotropins is dependent on their efficiency at the different levels of their action. The first level is their clearance rate from the circulation, the second is the ability to specifically recognize their receptor and the third is their efficacy in triggering specific target cell responses. The influence of gonadotropin structure on these three levels of hormone action will be considered.

\section{A. Structure and in vivo half-life.}

The in vivo activity of gonadotropins is highly dependent on their half-life in the general circulation, and the uptake of these hormones from the circulation occurs predominantly in the liver and kidneys.

The removal of sialic acid from hCG and eCG drastically diminishes their in vivo activity without affecting their binding to receptors (Yang and Papkoff, 1973). Thus sialic acid appears to have an important role in slowing down the clearance of these hormones. In the liver, hepatocyte membrane lectins have been characterized that bind glycoproteins through terminal Gal residues (PB1), leading to their internalization and degradation by the cells (Ashwell and Morell, 1974). The presence of terminal sialic acid residues (PB2) shielding Gal residues avoids the uptake of the hormone by hepatic lectins. Glycoproteins with terminal $\mathrm{N}$-acetylgalactosamine often have a very short half-life. It has thus been suggested that sulfate groups in these hormones play the same role as sialic acid residues and decrease their rate of clearance by blocking the terminal sugars (Hortin et al., 1981).

The circulatory half-life of hCG and eCG is quite a bit higher than that of pituitary gonadotropins (Markkanen et al., 1979 ; Aggarwal and Papkoff, 1981). However, recent data show that continuous infusion of desialylated fetuin does not influence the metabolic clearance rate of hCG, suggesting that there is negligible catabolism of hCG by a pathway that involves peripheral desialylation and subsequent hepatic uptake (Lefort et al., 1984). This observation is in keeping with previous observations that after injection of radiolabeled $\mathrm{hCG}$ into the rat, approximately $60 \%$ of the radioactivity accumulates in the kidneys and urine (Markkanen et al., 1979). Interestingly, urinary excretion occurs rapidly and without extensive degradation so that their variations in the circulation can be followed by immunoassay in urine (Lefort et al., 1986); active hormones for human clinical use are prepared from this source. Unfortunately, although gona- 
dotropins could possibly be largely removed from the circulation by glomerular filtration, this mechanism has received little attention and almost no information is available concerning the relationships between the structure of gonadotropins and their renal excretion.

\section{B. Structure and receptor binding.}

\section{Structure of hormone-receptor complexes.}

During the last few years many reports have been published concerning the purification and characterization of the receptors for $\mathrm{LH} / \mathrm{hCG}$ or $\mathrm{FSH}$. The detergent-solubilized receptors have been estimated to have a molecular weight of 200300000 . Although there is general agreement that they have an oligomeric structure, there is no concensus on the number of their subunits, molecular weight or the nature of the bonds holding them together. The different models proposed so far fall into two groups : a) the receptors are non-covalently bonded oligomers made of a single type of protomer of MW between 79000 and 100000 (Metsikkö, 1984) or $b$ ) they consist of different subunits joined either by noncovalent or disulfide bonds (Ji et al., 1985 ; Shin and Ji, 1985 ; Smith et al., 1986): It might be that the "subunits " are artefactually produced by proteolytic digestion of protomers (Ascoli and Segaloff, 1986). It has been shown that almost completely deglycosylated gonadotropins are still able to bind specifically to their receptors, indicating that their polypeptide moiety is entirely responsible for receptor recognition. The determination of the involvement of the $\alpha$ - and $\beta$ subunits in the binding of gonadotropins to their receptors has been mainly achieved by immunochemical analysis and by cross-linkage with bifunctionnal or photo-activable agents. Immunoglobulin Fab fragments directed against the bLH $\alpha$-subunit strongly inhibited the binding of bLH to rat testis receptors (Pierce $e t$ al., 1979). More recently, the use of monoclonal antibodies directed against epitopes from each subunit of hCG confirmed that both subunits were involved in the interaction with testicular (Moyle et al., 1982) or ovarian (Berger et al., 1984) receptors. Owing to the molecular size of immunoglobulins, the regions involved in the binding of gonadotropins to their receptors cannot be determined precisely because of important steric hindrance. Using short-range bifunctional or photoactivable reagents, covalent bonds have been established between the gonadotropins and their receptors after specific association. It appears that both subunits are cross-linked to receptor proteins, indicating that both are involved in the interaction with the receptor. This rules out the hypothesis that specific $\beta$ subunits alone contribute to the binding site and that the $\alpha$-subunit only serves as a template for its transconformation from an inactive to an active form.

\section{Structure and binding specificity.}

Specificity loop model. - By comparing the amino-acid sequences of $\beta$ subunits of glycoprotein hormones from different species, Ward and his 
colleagues (Moore et al., 1980) proposed that the specificity of each hormone is determined by the charge borne by a short peptide loop between S-S-linked halfcystines $\beta 93-\beta 100$. A net negative charge of -3 would lead to the expression of FSH activity while a net charge of 0 or +1 would give an $\mathrm{LH}$ character to the molecule. To explain the double activity of eCG, they propose that the Gin residue in position $\beta-94$ would be partly deamidated to its acidic counterpart Glu, thus leading to a diminished net charge of the so-called " specificity loop » which, in turn, would express either FSH alone or both FSH and LH activities.

There are several pieces of evidence against this hypothesis. First, eCG and eLH exhibit both LH and FSH activities in all species studied so far (Combarnous et al., 1978 ; Moore and Ward, 1980) but not in their species of origin (horse), where they express only LH activity (Moore and Ward, 1980 ; Combarnous et al., 1984a). Therefore, single or double activity is not an intrinsic property of gonadotropins only but depends on the structure of both the hormone and the receptor. A second argument is that eLH and eCG should exist as separate molecules with either FSH or LH activity. In contrast, it has been shown that all preparations of eCG or eLH have a constant FSH/LH activity ratio, whatever their purity, and that the two activities disappear concomitantly upon dissociation at acid pH (Combarnous et al., 1981 ; Guillou and Combarnous, 1983). Moreover, it has been recently demonstrated that isoforms of eLH have similar FSH/LH activity ratios in rat and porcine RRA (Matteri and Papkoff, 1987). It can thus be concluded that both activities are borne by the same molecules.

Negative specificity model. - Considering the fact that eCG and eLH express a type of activity (FSH) they don't have in their own species, we postulated that all glycoprotein hormones shared a common high-affinity site for their receptors but different specific inhibiting sites which impede the association of a given hormone to the receptor of another one (Combarnous, 1981; Combarnous and Hengé, 1981). The structure and/or positions of these inhibitory sites may differ with the species. Consequently, in heterologous systems they may not be in the correct position(s) to inhibit the binding of a given hormone to receptors for others. This inhibitory mechanism of binding specificity is reinforced by the observation that there is a $300 \%$ increase in the TSH activity of carboxypeptidase-treated hCG (Carayon et al., 1981), strongly suggesting that the removed portion inhibits the binding of the hormone to TSH receptors.

We postulate that the common high-affinity site is mainly contributed by the $\alpha$-subunit, while specific inhibiting sites are borne by each specific $\beta$-subunit. It has been recently shown (Kusuda and Dufau, 1986) that the $\alpha$-subunit of hCG undergoes predominant interaction with the rat ovarian receptor for $\mathrm{LH}$. This result is in very good agreement with our proposal that the common $\alpha$-subunit would bear the high affinity site of gonadotropins for their receptors.

\section{Structure and trans-membrane signaling.}

It is obvious that the effects of intracellular second messengers such as cAMP, diacylglycerol or inositol tri-phosphate do not depend at all on which hormone led to their production. By contrast, their level and production kinetics 
may differ under stimulation by one or another gonadotropin because the hormonal structure has a direct influence on the initial steps of stimulation at the plasma membrane level. We will now focus on the very first events corresponding to the transit of the hormonal message across the membrane.

1. Antagonists. - It has been shown in the past few years that removal of $70-75 \%$ of the total carbohydrate in gonadotropins leads to derivatives which are still able to bind to their specific receptors but unable to stimulate the corresponding adenylate cyclase system. This has been shown for oLH (Sairam and Fleshner, 1981), bLH (Sairam, 1982), hCG (Manjunath and Sairam, 1982), oFSH (Manjunath et al., 1982) ; in agreement with the above data, deglycosylated (DG) gonadotropins specifically antagonize the action of the corresponding native hormones.

Since $\mathrm{LH}$ and CG contain different peripheral branches and stimulate Leydig cells and granulosa cells through the same receptors, it is obvious that therminal sugars are not involved in the coupling of hormone binding with adenylate cyclase stimulation. Accordingly, the removal of sialic acid residues from hCG or eCG impairs neither their binding to $\mathrm{LH}$ receptors nor their activity in the stimulation of the production of cAMP, steroids or other specific products (Bahl and Moyle, 1978). Therefore, only the inner core of carbohydrate chains and/or the non-distal part of the peripheral branches are involved in transmembrane signaling.

It has been reported that the microaggregation of $\mathrm{LH}$ receptors by an anti- $\mathrm{LH}$ receptor antibody plus a second cross-linking antibody led to activation of rat Leydig cells (Podesta et al., 1983). This indicates that the biological information of the hormone-receptor complex resides in the receptor and not in the hormone. Therefore, the role of the hormone would be to aggregate adequately its specific receptors so that they can promote trans-membrane stimulation of second messenger production. In this respect one can imagine that carbohydrate chains bind to secondary binding sites of the receptors and promote their microaggregation (fig. 2). Consistent with this view, it has been reported that the glycopeptides of hCG $\alpha$ inhibited hCG-stimulated adenylate cyclase activity in rat luteal tissue without affecting significantly the binding of native hCG to its receptors (Calvo and Ryan, 1985).

2. Agonists. - A comparison of the activities of gonadotropins from different species at different levels of their action (binding, cAMP production, secretion of steroids or specific proteins) has evidenced that gonadotropins, upon binding, may show different efficiencies in their ability to trigger cellular response. In rat Sertoli cells, rFSH, oFSH, eLH, eCG, asialo-eCG and pFSH exhibited relative potencies in their stimulating activities (CAMP, estradiol and plasminogen activator (PA) productions) that were well correlated with their relative binding activities (Combarnous et al., 1984a). By contrast, eFSH has a much higher potency in stimulating CAMP and PA production than expected from its binding activity. Similar behaviour was observed for hCG (and to a lesser extent for oLH and $\mathrm{eLH}$ ) in rat Leydig cells. We coined the term " superactivity " to describe this 

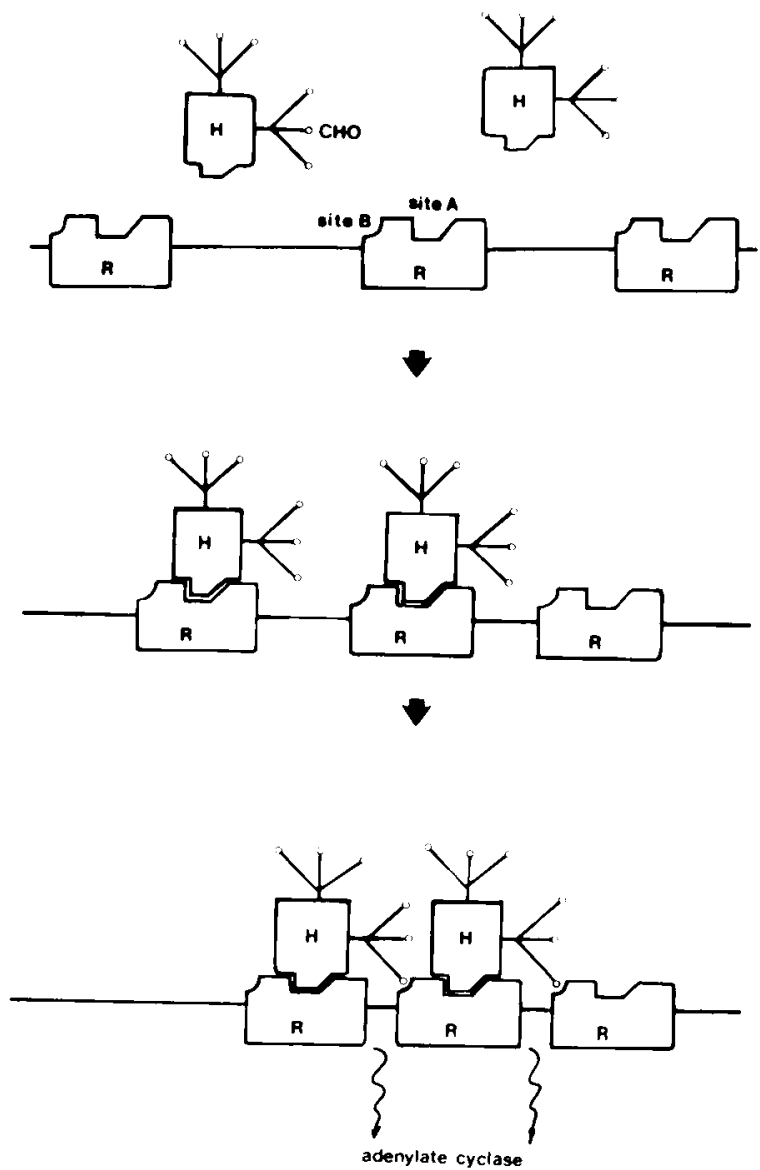

FIG. 2. - Hypothetical model of the role of carbohydrate moietites in transmembrane signaling. Specific high-affinity binding of the hormone $(H)$ to its receptor $(R)$ occurs at site $A$, and then some specific carbohydrate residue(s) of the hormone triggers micro-aggregation of the receptors by binding to site $B$ of a neighbor receptor. This micro-aggregation is believed to be involved in some way in the stimulation of adenylate cyclase activity.

phenomenon and found that this behavior was related to a long-lasting stimulation of adenylate cyclase activity in the corresponding target-cells compared to that elicited by other hormones (Segaloff et al., 1981 ; Guillou et al., 1986).

In recent years, hCG and $\mathrm{LH}$ actions have been shown to differ in many respects although they are mediated by the same receptors. Using the fluorescence photobleaching recovery technique, Niswender et al. (1985) demonstrated a substantially lower diffusion coefficient for hCG-receptor complexes than for oLH-receptor complexes in ovine luteal cell plasma membranes, indicating that the lateral movement of the receptor is modulated by the nature of the bound hormone. As DGhCG-receptor complexes behave like 
oLH-receptor complexes in this respect, it is obvious that the carbohydrate portion of hCG plays a primordial role in decreasing the mobility of the receptors for LH.

More recently, it was reported that $\mathrm{Na}^{+}$decreased the affinity of $\mathrm{LH}$ for its receptors but not that of hCG in Leydig tumor cells (Buettner and Ascoli, 1984). In fact, we demonstrated that $\mathrm{Na}^{+}$affected the association rates of both hormones to the receptors for $\mathrm{LH}$ in rat Leydig cells and concluded that $\mathrm{Na}^{+}$did not inhibit the binding of hCG because of the irreversibility of its binding to the receptors for LH (Combarnous et al., 1986). By contrast, the reversibility of oLH and $\mathrm{pLH}$ binding to receptors led to complete inhibition by sodium chloride.

Moreover, it has,been shown that the different hormones bound to the $\mathrm{LH}$ receptors undergo internalization at different rates (Sheela Rani and Moudgal, 1985 ; Mock et al., 1983). Porcine and rat LH, as well as eCG, are internalized much more rapidly than $\mathrm{eLH}$ and $\mathrm{oLH}$, and $\mathrm{hCG}$ is internalized at a still lower rate. All these data have been integrated in the following model we have recently proposed (Combarnous et al., 1986) :

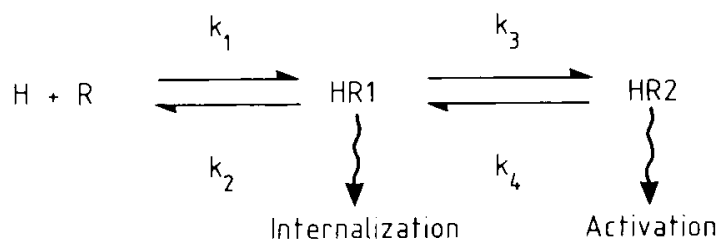

The primordial difference between $\mathrm{hCG}$ and $\mathrm{LH}$ is that the rate constant $\mathrm{k}_{4}$ is null or extremely low for hCG, higher for eLH and oLH and still higher for $\mathrm{rLH}$, $\mathrm{pLH}$ and eCG so that hCG-receptor complexes would be mainly in the $\mathrm{HR}_{2}$ functional state and $L H$ in the $H R_{1}$ state. The rate constant $k_{1}$ is diminished by $\mathrm{Na}^{+}$for all hormones but hCG binding is not inhibited because there is no back reaction $\mathrm{HR}_{2} \rightarrow H R_{1}$. Finally, internalization of $H R_{1}$ explains the transient stimulation by $\mathrm{LH}$ and the long-term action of $\mathrm{hCG}$. It can be concluded that the type of action is entirely dependent on the equilibrium between $\mathrm{HR}_{1}$ and $\mathrm{HR}_{2}$. It might be that the functional state $\mathrm{HR}_{2}$ corresponds to one of low mobility as found by fluorescence photobleaching recovery, and that this decreased mobility might arise from microaggregation (see above). If so, the carbohydrate moiety would be chiefly implicated in the equilibrium between the two states. For the time being, we have no experimental data to prove this hypothesis, and the structural origin of the superactivity of hCG may lie in its polypeptide portion. Nevertheless, it can be excluded that it is due to its carboxy-terminal extension in its $\beta$-subunit, since eCG also evidences this without exhibiting any character of superactivity. Moreover, eLH and eCG exhibit different degrees of superactivity (Combarnous et al., 1986) although their amino-acid sequences are identical (Bousfield et al., 1987).

\section{Extra-gonadic action}

The majority of uncombined $\alpha$-subunit in bovine pituitary is 0 -glycosylated. It might be that $\mathrm{O}$-glycosylation of this subunit plays a role in regulating dimer 
production. In the rat fetus, however, a functional role for the $\alpha$-subunit of glycoprotein hormones has been demonstrated (Bégeot et al., 1984). Indeed this subunit induces the development of lactotropes in 13-day fetus pituitary. This finding is of utmost importance for structure-function studies since the $\alpha$-subunit would have a biological role of its own in addition to its gonadotrope and thyreotrope actions in association with the different $\beta$-subunits. Consequently, some portions in its structure may have been conserved during evolution because of this role rather than because of its role in glycoprotein hormones.

\section{Conclusions and perspectives}

The available data summarized above demonstrate that protein and carbohydrate portions in gonadotropins clearly have different roles in the expression of their gonadotropic activities.

The polypeptide part is entirely responsible for specific recognition of membrane receptors and may also be involved in trans-membrane signaling. The distal residues of the carbohydrate moiety have a primordial role in maintaining the hormones in the circulation. The more proximal carbohydrate residues are directly involved in the transmission of the hormonal message across the membrane after binding to specific receptors.

The precise mechanism by which each subunit participates in hormonal action is not yet known with certainty, but all recent data clearly indicate that the two of them directly interact with the receptor.

A better knowledge of the structures involved at the different levels of hormone action will be highly helpful in determining the best gonadotropic preparations for each situation.

Reçu en octobre 1987.

Accepté en octobre 1987.

Résumé. Structure et relations structure - Activité des gonadotropines.

Une revue des travaux récents accomplis dans de nombreux laboratoires dont le nôtre, sur la structure et les relations structure-activité des gonadotropines est présentée.

La complexité de la structure de ces hormones tient à leur nature glycoprotéique (la partie polysaccharidique représentant 20 à $50 \%$ en masse de la molécule) et à leur structure quaternaire (association non-covalente de deux sous-unités différentes). Dans cette revue nous nous attachons à présenter les importances relatives des caractères structuraux de ces molécules pour leur activité aux différents niveaux de leur action (demivie dans la circulation, liaison aux récepteurs, transduction du signal). 


\section{References}

AGGARWAL B. B., PAPKOFF H., 1981. Studies on the disappearance of equine chorionic gonadotropin from the circulation in the rat: Tissue uptake and degradation. Endocrinology, 109, $1242 \cdot 1247$

ANOUASSI A., COMBARNOUS Y., LECOMPTE F., CAHOREAU C., GUILLOU F., 1987. Purification and characterization of Luteinizing hormone from the dromedary /Came/us dromedarius). Biochimie, 69, 647-654.

ASCOLI M., SEGALOFF, 1986. Effects of collagenase on the structure of the lutropin/choriogonadotropin receptors. J. biol. Chem., 261, 3807-3815.

ASHWELL G., MORELL A., 1974. The dual role of sialic acid in the hepatic recognition and catabolism of serum glycoproteins. Biochem. Soc. Symp., 40, 117-124.

BAHL O. P., MOYLE W. R., 1978. Role of carbohydrate in the action of gonadotropins. Recept. Hormone Act, 3, 261-289.

BÉGEOT M., HEMMING F. J., DUBOIS P. M., COMBARNOUS Y., DUBOIS M. P., AU. BERT M. L., 1984. Induction of pituitary lactotrope differentiation by luteinizing hormone $\alpha$ subunit. Science, 226, 566-568.

BERGER P., KOFLER R., WICK G., 1984. Monoclonal antibodies against human chorionic gonadotropin (hCG) : II. Affinity and ability to neutralize the biological activity of hCG. Am. J. Reprod. Immunol., 5, 157-160.

BEWLEY T. A., SAIRAM M. R., 1985. Conformation and dissociation-recombination of chemically deglycosylated ovine lutropin. Int. J. Peptide protein Res., 26, 612-620.

BIRKEN S., CANFIELD R. E., 1978. Structural and immunochemical properties of human chorigonadotropin. In MCKERNS K. W., Structure and function of the gonadotropins, Plenum Press N.Y., p. 47-80.

BLUM W. F. P., RIEGELBAUER G., GUPTA D., 1985. Heterogeneity of rat FSH by chromatofocusing : studies on in vitro bioactivity of pituitary FSH forms and effect of neuraminidase treatment. J. Endocr., 105, 17-27.

BOOTHBY M., RUDDON R. W., ANDERSON C., McWILLIAMS D., BOIME I., 1981. A single gonadotropin $\alpha$-subunit gene in normal tissue and tumor-derived cell lines. J. biol. Chem., 256, 5121-5128.

BOUSFIELD G. R., SUGINO H., WARD D. N., 1985. Demonstration of a $\mathrm{COOH}$-terminal extension on equine lutropin by means of a common acid-labile bond in equine lutropin and equine chorionic gonadotropin. J. biol. Chem., 260, 9531-9533.

BOUSFIELD G. R., LIU W.-K., SUGINO H., WARD D. N., 1987. Structural studies on equine glycoprotein hormones. Amino-acid sequence of equine lutropin-subunit. J. biol. Chem., 262, 86108620 .

BUETTNER K., ASCOLI M., 1984. $\mathrm{Na}^{+}$modulates the affinity of the lutropin/choriogonadotropin receptor. J. biol. Chem., 259, 15078-15084.

CALVO F. O., RYAN R. J., 1985. Inhibition of adenylyl cyclase activity in rat corpora luteal tissue by glycopeptides of human chorionic gonadotropin and the $\alpha$-subunit of human chorionic gonadotropin. Biochemistry, 24, 1953-1959.

CARAYON P., AMR S., NISULA B., LISSITZKY S., 1981. Effect of carboxypeptidase digestion of the human choriogonadotropin molecule on its thyrotropic activity. Endocrinology, 108, 18911898.

CHUNG D., SAIRAM M. R., LI C. H., 1973. The primary structure of ovine interstitial cell-stimulating hormone. III : disulfide bridges of the $\alpha$-subunit. Arch. Biochem. Biophys., 159, 678-682.

CHUNG D., SAIRAM M. R., LI C. H., 1975. The primary structure of ovine insterstitial cell-stimu lating hormone IV: disulfide bridges of the $\beta$-subunit. Int. J. Peptide Protein Res., 7. 487-494.

COMBARNOUS Y., 1976. Etude de l'hormone lutéinisante : purification, structure covalente et conformation. Th. Doct. Etat, Univ. Liège.

COMBARNOUS Y., 1981. Hypothèse originale sur la spécificité de liaison des hormones glycoprotéiques à leurs récepteurs. C. R. Acad. Sci. Paris, 293, 229-232.

COMBARNOUS Y., GUILLOU F., MARTINAT N., 1986. Functional states of the luteinizing hormone/ choriogonadotropin-receptor complex in the rat Leydig cells. J. biol. Chem., 261, 6868-6871. 
COMBARNOUS Y., GUILLOU F., MARTINAT N., 1984a. Comparison of in vitro follicle-stimulating hormone (FSH) activity of equine gonadotropins (luteinizing hormone, $\mathrm{FSH}$, and chorionic gonadotropin) in male and female rats. Endocrinology, 115, 1821-1827.

COMBARNOUS Y., GUILLOU F., MARTINAT N., CAHOREAU C., 1984b. Origine de la double activité $\mathrm{FSH}+\mathrm{LH}$ de la choriogonadotropine équine (eCG/PMSG). Ann. Endocr., 45, $261-268$.

COMBARNOUS Y., HENGE M.-H., 1981. Equine follicle-stimulating hormone. Purification, acid dissociation and binding to equine testicular tissue. J. biol. Chem., 256, 9567-9572.

COMBARNOUS Y., HENNEN G., 1974a. The disulfide bridges of porcine luteinizing hormone $\alpha$-subunit. Biochem. Soc. Trans., 2, 915-917.

COMBARNOUS Y., HENNEN G., 1974b. Luteinizing hormone derivatives with covalently-linked subunits. FEBS Lett., 44, 224-228.

COMBARNOUS Y., HENNEN G., 1976. Chemical study of the topography of porcine lutropin (LH) using dinitrofluorobenzene and dansyl chloride. Int. J. Peptide Protein Res., 8, 491-498.

COMBARNOUS Y., HENNEN G., KETELSLEGERS J. M., 1978. Pregnant-mare serum gonadotropin exhibits higher affinity for lutropin- than for follitropin receptors of porcine testis. FEBS Lett., 90, 65-68.

COMBARNOUS Y., MAGHUIN-ROGISTER G., 1974a. Luteinizing hormone. 1. Circular dichroism and spectrophotometric titration of porcine and bovine hormones and of their $\alpha$ - and $\beta$ subunits. Eur. J. Biochem., 42, 7-12.

COMBARNOUS Y., MAGHUIN-ROGISTER G., 1974b. Luteinizing hormone. 2. Relative reactivities of tyrosyl residues of the porcine hormone towards iodination. Eur. J. Biochem., 42, 13-19.

COMBARNOUS Y., SALESSE R., GARNIER J., 1981. Physico-chemical properties of pregnantmare serum gonadotropin. Biochim. Biophys. Acta, 667, 267-276.

CORNELL J. S., PIERCE J. G., 1974. Studies on the disulfide bonds of glycoprotein hormones: locations in the $\alpha$-chain based on partial reduction and formation of $14 \mathrm{C}$-labeled $\mathrm{S}$ carboxymethyl derivatives. J. biol. Chem., 249, 4166-4174.

COURTE C., HURAULT M., COMBARNOUS Y., DE LA LLOSA P., JUTISZ M., 1971. Isolation from ovine luteinizing hormone (LH) of several active components and their characterization. In MARGOULIES M., GREENWOOD F. C., Structure-activity relationships of protein and polypeptide hormones. Excerpta med. Fdn, Amsterdam, p. 362-365.

COURTE C., WILLEMOT J., 1972. Heterogeneity of porcine pituitary luteinizing hormone subunits ( $\mathrm{LH}_{x}$ and $\mathrm{LH} \beta$ ) in $5 \mathrm{M}$ guanidine hydrochloride agarose gel chromatography. J. biol. Chem., 247. 4429-4431.

FORASTIERI H., INGHAM K. C., 1982. Thermal stability of human chorionic gonadotropin. Reversible dissociation of subunits at neutral pH. J. biol. Chem., 257, 7976-7981.

FUJIKI Y., RATHNAM P., SAXENA, 1980. Studies on the disulfide bonds in human pituitary folliclestimulating hormone. Biochim. Biophys. Acta, 624, 428-435.

GARNIER J., PERNOLLET J. C., TERTRIN-CLARY C., SALESSE R., CASTEING M., BARNAVON M., DE LA LLOSA P., JUTISZ M., 1975. Conformational studies of ovine lutropin (luteinizing hormone) and its native and chemically modified subunits by circular dichroism and ultraviolet absorption spectroscopy. Eur. J. Biochem., 53, 243-254.

GIUDICE L. C., PIERCE J. G., 1978. Glycoprotein hormones : some aspects of studies of secondary and tertiary structure. In McKERNS, Structure and function of the gonadotropins, Plenum Press N.Y., p. 81-110.

GORDON W. L., WARD D. N., 1985. Structural aspects of luteinizing hormone actions. In ASCOLI M., Luteinizing hormone action and receptors. CRC Press, p. 173-197.

GOVERMAN J. M., PARSONS T. F., PIERCE J. G., 1982. Enzymatic deglycosylation of the subunits of chorionic gonadotropin. Effects on formation of tertiary structure and biological activity. $J$. biol. Chem., 257, 15059-15064.

GREEN E. D., BOIME I., BAENZINGER J. U., 1986. Biosynthesis of sulfated asparagine-linked oligosaccharides on bovine lutropin. J. biol. Chem., 261, 16309-16316.

GUILLOU F., COMBARNOUS Y., 1983. Purification of equine gonadotropins and comparative study of their acid-dissociation and receptor-binding specificity. Biochim. Biophys. Acta, 755, 229236 . 
GUILLOU F., MARTINAT N., COMBARNOUS Y., 1986. Study of the superactivity of equine follicle-stimulating hormone in in-vitro stimulation of rat Sertoli cells. Biochim. Biophys. Acta, 887, 196-203.

HATTORI M., OZAWA K., WAKABAYASHI K., 1985. Sialic acid moiety is responsible for the charge heterogeneity and the biological potency of rat lutropin. Biochem. Biophys. Res. Comm., 127, 501-508.

HORTIN G., NATOWICZ M., PIERCE J. G., BAENZIGER J., PARSONS T., BOIME I., 1981. Metabolic labeling of lutropin with $\left.{ }^{35} \mathrm{~S}\right]$ sulfate. Proc. nat. Acad. Sci. USA, 78, 7468-7472.

INGHAM K. C., WEINTRAUB B. D., EDELHOCH H., 1976. Kinetics of recombination of the subunits of human chorionic gonadotropin. Effect of subunit concentration. Biochemistry, 15, 1720-1726.

JI I., BOCK J. H., JI T. H., 1985. Composition and peptide maps of cross-linked human choriogonadotropin-receptor complexes on porcine granulosa cells. J. biol. Chem., 260, 12815-12821.

JUTISZ M., SQUIRE, 1958 . Occurrence of several active components in sheep pituitary interstitial cell-stimulating hormone as evidenced by column electrophoresis. Bull. Soc. Chim. biol., 40, $1875-1880$.

KESSLER M. J., MISE T., GHAI R. D., BAHL O. P., 1979. Structure and location of the O-glycosidic carbohydrate units of human chorionic gonadotropin. J. biol. Chem., 254, 7909-7914.

KUSUDA S., DUFAU M. L., 1986. Purification and characterization of the rat ovarian receptor for luteinizing hormone. J. biol. Chem., 261, 16161-16168.

LEFORT G. P., STOLK J. M., NISULA B. C., 1984. Evidence that desialylation and uptake by hepatic receptors for galactose-terminated glycoproteins are immaterial to the metabolism of human choriogonadotropin in the rat. Endocrinology, 115, 1551-1557.

LEFORT G. P., STOLK J. M., NISULA B. C., 1986. Renal metabolism of the $\beta$-subunit of human choriogonadotropin in the rat. Endocrinology, 119, 924-931.

LIU W.-K., WARD D. N., 1975. The purification and chemistry of pituitary glycoprotein hormones. Pharmac. Therap., 1, 545-570.

LIU W.-K., WARD D. N., 1976. Effect of selective nitration on ovine lutropin on the subunit association and biological activity of the hormone. J. biol. Chem., 251, 316-319.

MANJUNATH P., SAIRAM M. R., 1982. Biochemical, biological and immunological properties of chemically deglycosylated human choriogonadotropin. J. biol. Chem., 257, 7109-7115.

MANJUNATH P., SAIRAM M. R., 1983. Enhanced thermal stability of chemically deglycosylated human choriogonadotropin. J. biol. Chem., 258, 3554-3558.

MANJUNATH P., SAIRAM M. R., SAIRAM J., 1982. Studies on pituitary Follitropin. X. Biochemical, receptor binding and immunological properties of deglycosylated ovine hormone. Mol. cell. Endocr., 28, 125-138.

MARKKANEN S., TÖLLIKKÖ K., VANHA-PERTULLA T., RAJANIEMI H., 1979. Disappearance of human 125 | iodochorionic gonadotropin from the circulation in the rat: tissue uptake and degradation. Endocrinology, 104, 1540-1547.

MATTERI R. L., PAPKOFF H., 1987. Characterization of equine luteinizing hormone by chromatofocusing. Biol. Reprod., 36, 261-269.

METSIKKÖ M. K., 1984. Covalent labelling of the lutropin binding site; evidence for a single Mr 90000 sialoglycoolypeptide. Biochem. J., 219, 583-591.

MISE T., BAHL O. P., 1980. Assignment of disulfide bonds in the $\alpha$-subunit of human chorionic gonadotropin. J. biol. Chem., 255, 8516-8522.

MOCK E. J., PAPKOFF H., NISWENDER G. D., 1983. Internalization of ovine luteinizing hormone/ human chorionic gonadotropin recombinants : Differential effects of the $\alpha$-and $\beta$-subunits. Endocrinology, 113, 265-269.

MOORE W. T., BURLEIGH B. D., WARD D. N., 1980. Chorionic gonadotropins : Comparative studies and comments on relationships to other glycoprotein hormones. In SEGAL S. J., Chorionic gonadotropin, Plenum Press N.Y., p. 89-126.

MOORE W. T., WARD D. N., 1980. Pregnant mare serum gonadotropin. An in vitro biological characterization of the lutropin-follitropin dual activity. J. biol. Chem., 255, 6930-6936.

MOYLE W. R., EHRLICH P. H., CANFIELD R. E., 1982. Use of monoclonal antibodies to subunits of human chorionic gonadotropin to examine the orientation of the hormone in its complex with receptor. Proc. nat. Acad. Sci. USA, 79, 2245-2249. 
NILSSON B., ROSEN S. W., WEINTRAUB B. D., ZOPF D. A., 1986. Differences in the carbohydrate moieties of the common $\alpha$-subunits of human chorionic gonadotropin, luteinizing hormone, follicle-stimulating hormone and thyrotropin : preliminary structural inferences from direct methylation analysis. Endocrinology, 119, 2737-2743.

NISHIMURA R., HAMAMOTO T., UTSUNOMIYA T., MOCHIZUKI M., 1983. Heterogeneity of free alpha-subunit in term placenta. Endocrinol. jap., 30, 663-669.

NISWENDER G. D., ROESS D. A., SAWYER H. R., SILVIA W. J., BARISAS B. G., 1985. Differences in the lateral mobility of receptors for luteinizing hormone $(\mathrm{LH})$ in the luteal cell plasma membrane when occupied by ovine LH versus human chorionic gonadotropin. Endocrinology, 116, 164-169.

NWOKORO N., CHEN H.-C., CHRAMBACH A., 1981. Physical, biological and immunological characterization of highly purified urinary human chorionic gonadotropin components separated by gel electrophoresis. Endocrinology, 108, 291-299.

PARSONS T. F., BLOOMFIELD G. A., PIERCE J. G., 1983. Purification of an alternate form of the $\alpha$-subunit of the glycoprotein hormones from bovine pituitaries and identification of its $\mathrm{O}$ linked oligosaccharide. J. biol. Chem., 258, 240-244.

PARSONS T. F., PIERCE J. G., 1979. Biologically active covalently cross-linked glycoprotein hormones and the effects of modification of the $\mathrm{COOH}$-terminal region of their $\alpha$-subunits. $J$. biol. Chem., 254, 6010-6015.

PARSONS T. F., PIERCE J. G., 1984. Free $\alpha$-like material from bovine pituitaries. Removal of its O-linked oligosaccharide permits combination with lutropin-13. J. biol. Chem., 259, 2662-2666.

PIERCE J. G., 1976. Structural homologies of glycoprotein hormones. Excerpta med. Int. Congr. Series 403, 99-103.

PIERCE J. G., BLOOMFIELD G. A., PARSONS T. F., 1979. Purification and receptor, binding properties of complexes between lutropin and monovalent antibodies against its $\alpha$-subunit. Int. J. Peptide Protein Res., 13, 54-61.

PODESTA E. J., SOLANO A., ATTAR R., SANCHEZ M. L., MOLINA Y VEDIA L., 1983. Receptor aggregation induced by antilutropin receptor antibody and biological response in rat Leydig cells. Proc. nat. Acad. Sci. USA, 80, 3986-3990.

REEVE J. R., CHENG K. W., PIERCE J. G., 1975. Partial reduction of disulfide bonds in the hormonespecific subunits of TSH and LH. Biochem. Biophys. Res. Comm., 67, 149-155.

SAIRAM M. R., 1982. Effects of carbohydrate removal on the structure and activity of bovine lutropin. Biochim. Biophys. Acta, 717, 149-153.

SAIRAM M. R., FLESHNER P., 1981. Inhibition of hormone-induced cyclic AMP production and steroidogenesis in interstitial cells by deglycosylated lutropin. Mol. cell. Endocr., 22, 41-54.

SAIRAM M. R., MANJUNATH P., 1982a. Comparison of the thermal stability characteristics of native and deglycosylated ovine pituitary lutropin. Int. J. Peptide Protein Res., 19, 315-320.

SAIRAM M. R., MANJUNATH P., 1982b. Studies on pituitary follitropin. XII. Enhanced thermal stability induced by chemical deglycosylation. Mol. cell. Endocr., 28, 151-159.

SEGALOFF D. L., PUETT D., ASCOLI M., 1981. The dynamics of the steroidogenic response of perifused Leydig tumor cells to human chorionic gonadotropin, ovine luteinizing hormone, cholera toxin and adenosine $3^{\prime} 5^{\prime}$-cyclic monophosphate. Endocrinology, 108, 632-638.

SHEELA RANI C. S., MOUDGAL N. R., 1985. Differences in the behavior of luteinizing hormones of various species at the gonadal cell receptor site. Endocrinology, 116, 597-603.

SHIN J., JI T. H., 1985. Intersubunit disulfides of the follitropin receptor. J. biol. Chem., 260, 12828-12831.

SMITH R. A., BRANCA A. A., REICHERT L. E., 1986. Quaternary structure of the calf follitropin receptor. J. biol. Chem., 261, 9850-9853.

STOCKELL HARTREE A., LESTER J. B., SHOWNKEEN R. C., 1985. Studies of the heterogeneity of human pituitary LH by fast protein liquid chromatography. $J$. Endocr., 105, 405-413.

STRICKLAND T. W., PARSONS T. F., PIERCE J. G., 1985. Structure of LH and hCG. In ASCOLI M., Luteinizing hormone action and receptors. CRC Press, p. 1-15.

STRICKLAND T. W., PIERCE J. G., 1985. The $\beta$-subunits of glycoprotein hormones. Formation of three dimensional structure during cell-free biosynthesis of lutropin- $\beta$. J. biol. Chem., 260 , 5816-5819. 
STRICKLAND T. W., PUETT D., 1982. The kinetic and equilibrium parameters of subunit association and gonadotropin dissociation. J. biol. Chem., 257, 2954-2960.

TSUNASAWA S., LIU W. K., BURLEIGH B. D., WARD D. N., 1977. Studies of disulfide bond location in ovine lutropin $\beta$-subunit. Biochim. Biophys. Acta, 492, 340-347.

WARD D. N., GLENN S. D., NAHM H. S., WEN T., 1986. Characterization of cleavage products in selected human lutropin preparations. A protease sensitive site in human lutropin $\beta$ subunit. Int. J. Peptide Protein Res., 27, 70-78.

WEARE J. A., REICHERT L. E., 1979a. Studies with carbodiimide-cross-linked derivatives of bovine lutropin. I. The effects of specific group modifications on receptor site binding in testes. $J$. biol. Chem., 254, 6964-6971.

WEARE J. A., REICHERT L. E., 1979b. Studies with carbodiimide-cross-linked derivatives of bovine lutropin. II. Location of the cross-link and implication for interaction with the receptors in testes. J. biol. Chem., 254, 6972-6979.

WIDE L., 1982. Male and female forms of human follicle-stimulating hormone in serum. J. clin. Endocr. metab., 55, 682-688.

YANG K.-P., WARD D. N., 1972. lodination of ovine luteinizing hormone and its subunits. Endocrinology, 91, 317-320.

YANG W. H., PAPKOFF H., 1973. Effect of desialylation on ovulation-inducing activity of oLH, oFSH, PMSG and hCG in the hamster. Fertil. Steril., 24, 633-639. 